\title{
Genetic variation and population structure of the mixed-mating cactus, Melocactus curvispinus (Cactaceae)
}

\author{
JAFET M. NASSAR*††, J. L. HAMRICK§ \& THEODORE H. FLEMING $\dagger$ \\ $\dagger$ University of Miami, Biology Department, PO Box 249118, Coral Gables, FL 33124, U.S.A., \$Instituto Venezolano de \\ Investigaciones Cientificas, Centro de Ecología, Apdo. 21827, Caracas 1020-A, Venezuela and §University of \\ Georgia, Departments of Botany and Genetics, 2502 Plant Sciences, Athens, GA 30602, U.S.A.
}

\begin{abstract}
Genetic diversity was measured in the mixed-mating cactus, Melocactus curvispinus, in Venezuela. Allozyme diversity was surveyed in 19 putative loci over 18 populations. Compared to other plant taxa, this cactus is rich in polymorphic loci $\left(P_{\mathrm{s}}=89.5 \%\right)$, with high numbers of alleles per polymorphic locus $\left(A P_{\mathrm{s}}=3.82\right)$, but moderate levels of heterozygosity $\left(H_{\mathrm{es}}=0.145\right)$. Substantial levels of inbreeding were detected across loci and populations at macrogeographic $\left(F_{\mathrm{IS}}=0.348\right)$ and regional levels $\left(F_{\text {IS }}=0.194-0.402\right)$. Moderate levels of genetic differentiation among populations were detected at macrogeographical $\left(F_{\mathrm{ST}}=0.193\right)$ and regional $\left(F_{\mathrm{ST}}=0.084-0.187\right)$ scales, suggesting that gene flow is relatively restricted, but increases within regions without topographic barriers. The population genetic structure observed for this cactus was attributed to, at least, three factors: shortdistance pollination and seed dispersal, the mixed-mating condition of the species, and genetic drift. High genetic identities between populations $(I=0.942)$ supported the conspecific nature of all populations surveyed. The levels and patterns of genetic structure observed for $M$. curvispinus were consistent with its mating system and gene dispersal mechanisms.
\end{abstract}

Keywords: Cactaceae, genetic diversity, genetic structure, Melocactus, mixed mating, Venezuela.

\section{Introduction}

Genetic variation in xerophilous long-lived plants has rarely been examined and available estimates are considerably heterogeneous across species (MartinezPalacios et al., 1999; Hamrick et al., 2001). In the Cactaceae, with close to 1600 recognized species (Gibson \& Nobel, 1990), fewer than 15 taxa have been the subject of genetic diversity surveys (Nassar, 1999; Hamrick et al., 2001). Based on these studies, cacti can be described as having high levels of genetic diversity and relatively low population differentiation. These conclusions, however, are biased towards columnar cacti with predominantly outcrossing breeding systems and bat and bird pollination and seed dispersal.

For a more representative view of genetic diversity in cacti, species with contrasting life-history and ecological traits should be examined. Cacti with different mating and gene dispersal systems would be valuable subjects of

*Correspondence: Instituto Venezolano de Investigaciones Científicas, Biblioteca 'Marcel Roche', 8424 NW 56 Street, Suite CCS 00206, Miami, FL 33166, U.S.A. E-mail: jnassar@ oikos.ivic.ve study in this respect, because these two factors influence the distribution of genetic variation in seed plants (Loveless \& Hamrick, 1984; Hamrick \& Godt, 1989). In general, selfing and mixed-mating plant species have less genetic variation and more genetic differentiation among populations than outcrossing species. Although less predictive than mating systems, extensive pollen and seed dispersal are associated with high levels of withinpopulation genetic diversity and low population subdivision.

Melocactus is one of the most distinctive and widely distributed genera of cacti, with 24 species ranging from Mexico to Brazil and Peru, including also part of the Caribbean (Taylor, 1991). This genus represents the most derived group within the Cereeae tribe, with a relatively reduced size $(<30 \mathrm{~cm})$, absence of branches, and a unique woolly apical cephalium containing the reproductive structures (Gibson \& Nobel, 1990; Taylor, 1991). According to Taylor (1991), most species are self-compatible, but floral adaptations promote hummingbird-mediated cross-pollination. Hand pollination experiments conducted in Venezuela on $M$. curvispinus Pfeiffer demonstrated that this species can produce seeds 
by selfing (N. Ramírez, pers. comm.). Population-and family-level rates of outcrossing in this species were estimated by Nassar (1999) for a single Venezuelan population. For this population, the species behaved as a facultatively xenogamous species, with a mean outcrossing rate of 0.764 and a wide range of variation of individual rates of outcrossing $\left(t_{\mathrm{m}}=0.18-1.00\right)$. Taylor (1991) also suggested that territorial behaviour in the hummingbirds that pollinate Melocactus species may further constrain gene flow. Together, selfing and potentially restricted gene dispersal in Melocactus species should promote less within-population genetic diversity and more genetic differentiation among populations than levels reported for predominantly outcrossing, longdistance dispersed columnar cacti sharing similar habitats and spatial ranges. We tested these predictions on M. curvispinus, a species broadly distributed in Venezuela that overlaps in range with other cacti for which data on allozyme diversity already exist (Nassar, 1999).

In this study we examined levels and patterns of allozyme genetic diversity in $M$. curvispinus across its entire range in Venezuela and compared these estimates with allozyme data available from other cacti with similar geographical ranges.

\section{Materials and methods}

\section{Study system}

Melocactus curvispinus, commonly known as 'buche' or 'melon', ranges from Mexico to northern South America, including part of the Caribbean. Two subspecies have been distinguished in Venezuela, M. curvispinus spp. curvispinus and M. curvispinus spp. caesius (Taylor, 1991). M. curvispinus spp. curvispinus is discontinuously distributed in the southwestern part of the country. M. curvispinus spp. caesius is distributed along the coast, from the Goajira Peninsula (west) to the Araya Peninsula and Margarita island (east). This species ranges from sea level to $1250 \mathrm{~m}$ and is always associated with arid and semiarid environments on a variety of soil types.

Melocactus curvispinus is a diploid cactus $(2 \mathrm{n}=22$; Das et al., 1998), easy to distinguish morphologically by its depressed-globose body, less than $30 \mathrm{~cm}$ tall at maturity. Adult plants develop a conspicuous cephalium, made of white woolly fibres intermixed with tightly clustered reddish bristles. Flowers are present only in the cephalium and are hermaphroditic and herkogamous, relatively small and solitary, with part of the floral tube exserted above the wool. Floral buds remain within the cephalium until less than $24 \mathrm{~h}$ before anthesis. The magenta flowers open during the afternoon and close by sunset on the same day. Few flowers (1-3) open simultaneously on the same individual. Episodic flower- ing occurs during most of the year; however, peak blooming and fruiting occurs during months with high precipitation (August-October) (J. Nassar, unpubl. data). This species is self-compatible (Taylor, 1991; Nassar, 1999; Ramírez, pers. comm.), however, several floral characteristics, including exerted stigma, bright colouration, and nectar production, suggest adaptations for outcrossing. Pollination is mainly performed by hummingbirds and, to a lesser extent, by solitary bees and butterflies (Taylor, 1991; J. Nassar, pers. observation). Fruits are chili-like berries, magenta or red and multiple-seeded. Seed dispersal occurs by lizards and birds (Taylor, 1991; Côrtes-Figueira et al., 1994). Individuals are solitary or occur in clusters. Population densities can be as high as 1290 individuals $\mathrm{ha}^{-1}$ (this study).

\section{Study sites}

This study was conducted in the main arid and semiarid zones of Venezuela (Fig. 1a), which include the coastline, islands and an extensive area along a North-South axis in the western part of the country. The latter includes extensive areas with xerophilous vegetation but also isolated xeric patches across the Venezuelan Andes.

Localities sampled, geographical coordinates, altitude and population density information are summarized in Table 1. Two spatial scales were considered: macrogeographical, including populations over all Venezuela (Fig. 1a), and regional, including populations within two geographically restricted areas, the Mainland region (Fig. 1b) and the Peninsula region (Fig. 1c). The Mainland region $\left(9^{\circ} 49^{\prime}-10^{\circ} 19^{\prime} \mathrm{N}\right.$ and $\left.69^{\circ} 28^{\prime}-70^{\circ} 06^{\prime} \mathrm{W}\right)$ is located in the largest continuous extension of arid lands, in western Venezuela. The Peninsula region $\left(11^{\circ} 56^{\prime}-\right.$ $11^{\circ} 58^{\prime} \mathrm{N}$ and $\left.69^{\circ} 56^{\prime}-70^{\circ} 01^{\prime} \mathrm{W}\right)$ corresponds to the Paraguaná Peninsula, in the northwestern coast. Each of these regions comprises an area approximately $56 \times 70 \mathrm{~km}$.

\section{Sampling and electrophoretic procedures}

Eighteen populations were studied at the macrogeographical scale and five populations were selected from both the Mainland and Peninsula regions. Forty-eight individuals separated by at least $10 \mathrm{~m}$ were selected from each site. Viable seeds were obtained from one fruit per individual and stored in dry conditions. Seeds were germinated directly in trays with potting soil and kept indoors for two weeks before being placed in greenhouse facilities at the University of Georgia, Athens, GA, U.S.A. One seedling was used from each individual sampled from each population, for a total of 864 seedlings analysed.

(C) The Genetics Society of Great Britain, Heredity, 87, 69-79. 
A

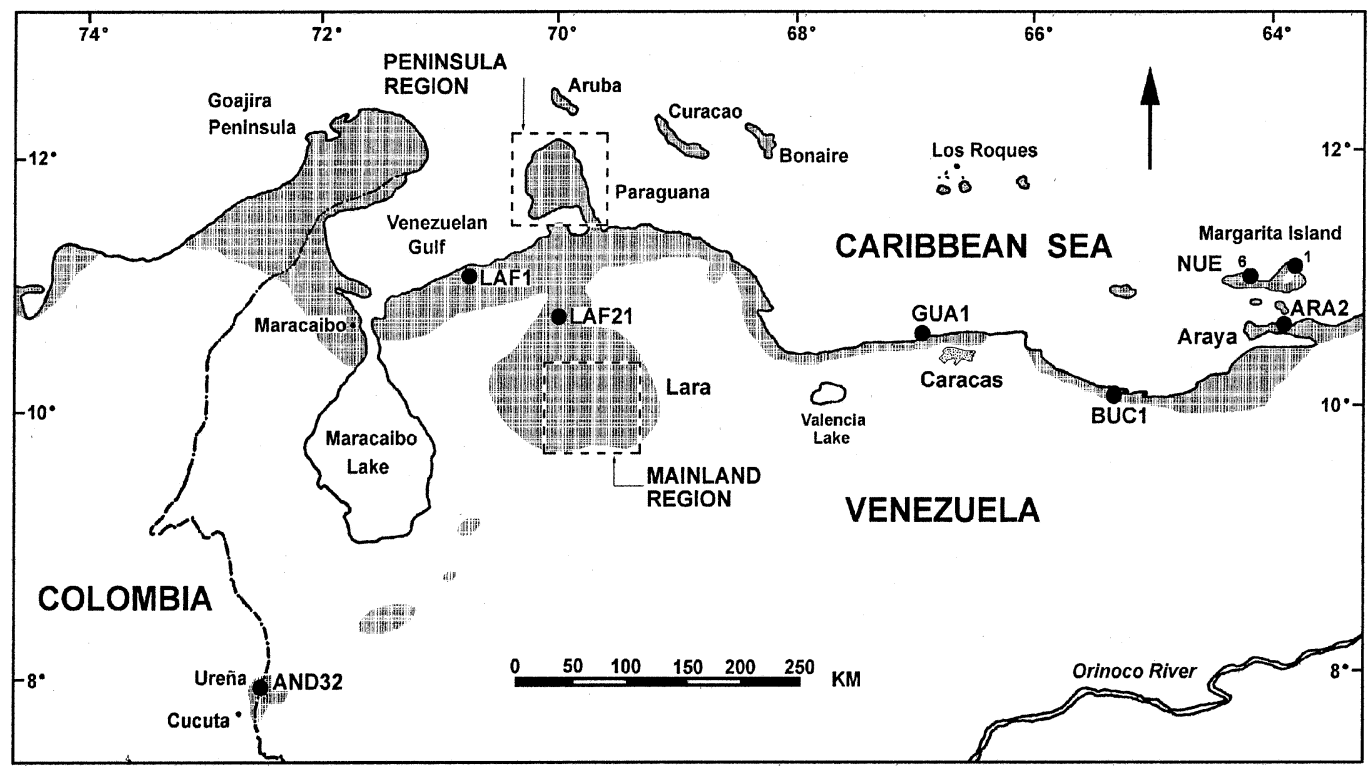

MAINLAND REGION

B

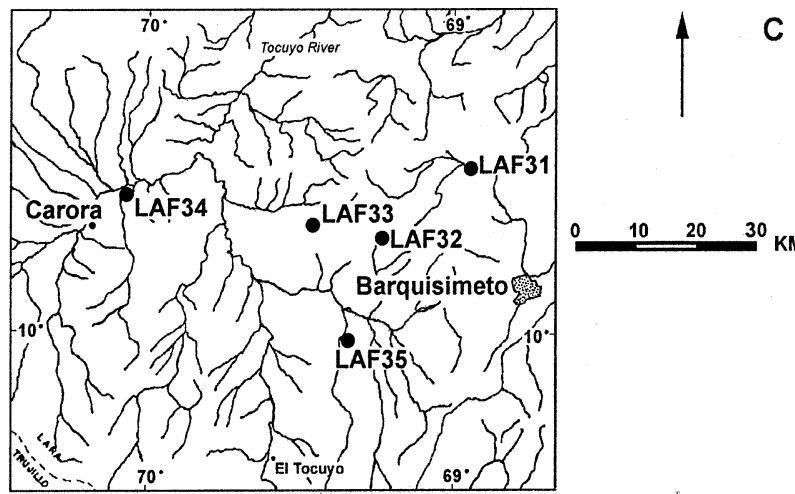

PENINSULA REGION

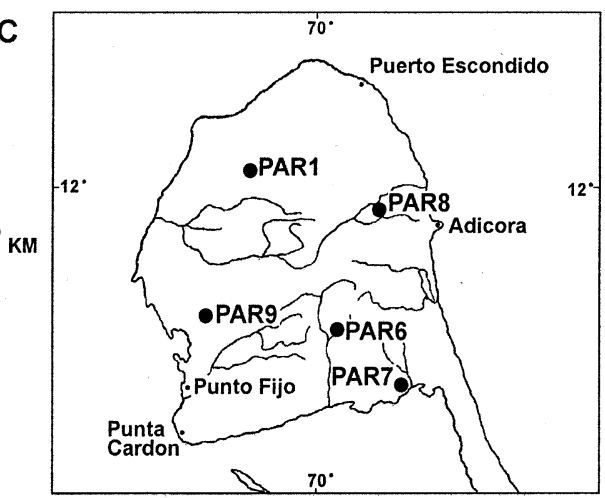

Fig. 1 Maps of Venezuela (a), Mainland region (b) and Peninsula region (c), showing locations where populations of Melocactus curvispinus were sampled. Names of locations and additional geographical information are included in Table 1. Shaded areas correspond to arid and semiarid lands (Sarmiento, 1976). The distribution of the species closely fits the distribution of arid lands in Venezuela.

One-cm tall seedlings were ground using sand, cold mortar and pestle. A PVP-phosphate extraction buffer (Wendel \& Parks, 1982) was added to the tissue to solubilize and stabilize the enzymes. Chromatography paper wicks (Whatman $3 \mathrm{MM}$ ) were soaked with the protein extracts, placed into microtest plates and stored at $-70^{\circ} \mathrm{C}$ prior to analysis. Horizontal electrophoresis was conducted on $11 \%$ potato starch gels (Sigma). Combinations of four buffer systems and 12 enzyme stains were used to resolve 19 putative loci: Buffer 4 with isocitrate dehydrogenase (Idh-l) and phosphoglucoisomerase (Pgi-1); buffer 8 with aspartate aminotransferase (Aat-1 and Aat-2), glutamate dehydrogenase
$(G d h-1)$ and triose-phosphate isomerase (Tpi-1 and Tpi-2); buffer 11 with malate dehydrogenase ( $M d h-1$, $M d h-2$ and $M d h-3)$, phosphoglucomutase (Pgm-1 and $P g m-2)$ and uridine diphosphoglucose pyrophosphorylase (Ugpp-1 and Ugpp-2); and buffer 34 with diaphorase (Dia-1 and Dia-2), fluorescent esterase ( $\mathrm{Fe}-2)$, leucine aminopeptidase (Lap-l) and menadione reductase (Mnr-1). Recipes of buffers and stains are modified from Soltis et al. (1983) with the exception of buffer 34 (Mitton et al., 1979) and enzyme systems Aat and Dia (Cheliak \& Pitel, 1984). Loci and alleles were designated based on relative protein mobility, with lower numbers assigned to those farther away from the origin. 
Table 1 Sampling localities of Melocactus curvispinus in Venezuela. Populations with prefix LAF3 correspond to the Mainland region and populations with prefix PAR correspond to the Peninsula region

\begin{tabular}{llcccc}
\hline Site ID & \multicolumn{1}{c}{ Locality } & Latitude N & Longitude W & Altitude $(\mathrm{m})$ & Density $\left(\right.$ Ind ha $\left.{ }^{-1}\right)$ \\
\hline AND32 & Ureña & $07^{\circ} 51^{\prime} 40^{\prime \prime}$ & $72^{\circ} 26^{\prime} 14^{\prime \prime}$ & $350-400$ & 1292.5 \\
ARA2 & Vía Chacopata & $10^{\circ} 39^{\prime} 22^{\prime \prime}$ & $63^{\circ} 45^{\prime} 33^{\prime \prime}$ & $0-20$ & 307.5 \\
BUC1 & Boca de Uchire & $10^{\circ} 06^{\prime} 24^{\prime \prime}$ & $65^{\circ} 22^{\prime} 31^{\prime \prime}$ & $0-20$ & 147.5 \\
GUA1 & La Guaira & $10^{\circ} 53^{\prime} 10^{\prime \prime}$ & $67^{\circ} 02^{\prime} 30^{\prime \prime}$ & $200-300$ & 320.0 \\
LAF1 & Sta. Rosa & $11^{\circ} 07^{\prime} 36^{\prime \prime}$ & $69^{\circ} 32^{\prime} 02^{\prime \prime}$ & 60 & 207.5 \\
LAF21 & Juan Gil & $10^{\circ} 53^{\prime} 00^{\prime \prime}$ & $69^{\circ} 45^{\prime} 26^{\prime \prime}$ & $200-250$ & 317.5 \\
LAF31 & Mesa de Urigua & $10^{\circ} 13^{\prime} 46^{\prime \prime}$ & $69^{\circ} 27^{\prime} 30^{\prime \prime}$ & $700-750$ & 307.5 \\
LAF32 & Banco de Baragua & $10^{\circ} 07^{\prime} 49^{\prime \prime}$ & $69^{\circ} 35^{\prime} 3^{\prime \prime}$ & $750-800$ & 227.5 \\
LAF33 & Turturia & $10^{\circ} 08^{\prime} 06^{\prime \prime}$ & $69^{\circ} 43^{\prime \prime} 02^{\prime \prime}$ & $600-650$ & 90.0 \\
LAF34 & Aregue & $10^{\circ} 13^{\prime} 18^{\prime \prime}$ & $70^{\circ} 03^{\prime} 20^{\prime \prime}$ & $350-400$ & 515.0 \\
LAF35 & Guadalupe & $10^{\circ} 02^{\prime} 00^{\prime \prime}$ & $69^{\circ} 40^{\prime} 30^{\prime \prime}$ & $550-600$ & 355.0 \\
NUE1 & Pampatar & $11^{\circ} 00^{\prime} 52^{\prime \prime}$ & $63^{\circ} 47^{\prime} 04^{\prime \prime}$ & $20-50$ & 482.5 \\
NUE6 & Guaratara & $11^{\circ} 14^{\prime} 10^{\prime \prime}$ & $64^{\circ} 12^{\prime \prime} 28^{\prime \prime}$ & $20-60$ & 197.5 \\
PAR1 & San José de Acaboa & $12^{\circ} 00^{\prime} 56^{\prime \prime}$ & $70^{\circ} 06^{\prime} 36^{\prime \prime}$ & 60 & 352.5 \\
PAR6 & Santa Ana & $11^{\circ} 47^{\prime} 00^{\prime \prime}$ & $69^{\circ} 58^{\prime} 33^{\prime \prime}$ & 40 & 1002.5 \\
PAR7 & Tacuato & $11^{\circ} 42^{\prime} 40^{\prime \prime}$ & $69^{\circ} 50^{\prime} 16^{\prime \prime}$ & $0-20$ & 170.0 \\
PAR8 & Santa Cruz & $11^{\circ} 58^{\prime} 30^{\prime \prime}$ & $69^{\circ} 53^{\prime \prime} 70^{\prime \prime}$ & 80 & 500.0 \\
PAR9 & Guanadito & $11^{\circ} 46^{\prime} 52^{\prime \prime}$ & $70^{\circ} 10^{\prime} 40^{\prime \prime}$ & $20-40$ & 307.5 \\
\hline
\end{tabular}

\section{Data analysis}

Allele frequencies and standard genetic diversity parameters (Berg \& Hamrick, 1997) were estimated at the species (subscript 's'), regional (Mainland and Peninsula regions, subscript ' $r$ ') and population (subscript ' $p$ ') levels, using the program LYNSPROG, written by M.D. Loveless (Department of Biology, College of Wooster, Wooster, OH) and A.F. Schnabel (Department of Biology, University of Indiana, South Bend, IN). The following parameters were estimated: proportion of polymorphic loci $(P)$, mean number of alleles per locus $(A)$ and per polymorphic locus $(A P)$, observed heterozygosity $\left(H_{\mathrm{o}}\right)$ and expected heterozygosity or genetic diversity $\left(H_{\mathrm{e}}=1-\sum p_{i}^{2}\right)$. These estimates were calculated for each locus and then averaged over all loci. Withinpopulation estimates were averaged over all populations to obtain means and standard errors. In addition, the percentage of alleles per population relative to the total number of alleles scored for the species $(\% \mathrm{Al})$ was determined. Departures from Hardy-Weinberg expectations were examined for each polymorphic locus in each population using a probability test (exact $\mathrm{H}-\mathrm{W}$ test; Rousset \& Raymond, 1995). We tested for genotypic linkage disequilibrium between each pair of loci across all populations performing probability tests on contingency tables using a Markov chain method (Garnier-Gere \& Dillman, 1992). Both tests were conducted with the program GENEPOP v.3.2a (Raymond \& Rousset, 1995a).

Partitioning of genetic variation was performed at both macrogeographical and regional scales. In the former, we considered populations over the entire geographical range of the species in Venezuela (Fig. 1a). To ensure the macrogeographical dimension of the analysis, only one population was randomly chosen from the Mainland and Peninsula regions (one from each). For the regional scale, only populations within the Mainland and Peninsula regions were selected (Fig. 1b, c). Nei's (1977) total genetic diversity $\left(H_{\mathrm{T}}\right)$ and mean genetic diversity within populations $\left(H_{\mathrm{S}}\right)$ were estimated for each polymorphic locus, using the program LYNSPROG. Allele frequency heterogeneity among populations was tested for polymorphic loci by conducting probability tests (Markov chain method; Raymond \& Rousset, 1995b), using the program GENEPOP. F-statistics following Weir \& Cockerham (1984) were estimated using the program FSTAT v.1.2, written by J. Goudet (I.Z.E.A., Switzerland). Overall means and standard errors of $F_{\mathrm{IS}}$ and $F_{\mathrm{ST}}$ across loci were calculated in two ways: (a) as arithmetic means with their standard errors; and (b) as pooled estimates, weighting the contribution of each locus by the genetic diversity at each locus, and jackknifing over loci to generate the standard error. Significant differences from zero in the $F$-statistic estimates were tested using permutations for each locus (alleles within samples for $F_{\text {IS }}$ and multilocus genotypes among samples for $F_{\mathrm{ST}}$ ).

Isolation by distance was tested using Rousset's (1997) method, based on the computation of a linear regression of pairwise $F_{\mathrm{ST}} /\left(1-F_{\mathrm{ST}}\right)$ estimates to the natural logarithm of geographical distances between pairs of populations. The program GENEPOP was used 
for this test. A positive correlation between the two variables is indicative of isolation by distance. A Mantel test of association (10 000 permutations) between pairwise $F_{\mathrm{ST}} /\left(1-F_{\mathrm{ST}}\right)$ and $\ln$ of geographical distance matrices was used to test for significance of the isolation-by-distance pattern (Heywood, 1991).

Nei's (1972) genetic identities $(I)$ and distances $(D)$ were estimated between all pairs of populations to generate average linkage clusterings using the unweighted pair group method with averaging (UPGMA) (Romesburg, 1984). Phenograms plotted using this procedure help to visualize genetic relationships between populations. UPGMA phenograms were performed using the program NTSYS-PC v.1.8 (Rohlf, 1993).

\section{Results}

\section{Genetic diversity}

Sixty-six alleles were resolved across all populations and loci. At the species level, $89.5 \%$ of loci were polymorphic (Table 2). The average number of alleles per locus was $3.53\left(A_{\mathrm{s}}\right)$ and per polymorphic locus $\left(A P_{\mathrm{s}}\right)$ was 3.82 . The overall genetic diversity $\left(H_{\mathrm{es}}\right)$ was 0.145 . Genetic diversity parameters were estimated separately for the Mainland and Peninsula regions. All genetic diversity estimates were higher in the Mainland region with the exception of $P_{\mathrm{r}}$. In particular, the pooled expected heterozygosity $\left(H_{\mathrm{er}}\right)$ varied from 0.093 in the Peninsula region to 0.157 in the Mainland region, however, population differences between the two regions were not statistically significant (Mann-Whitney test, $U=6$, NS). The average percentage of alleles captured in a given population $(\% \mathrm{Al})$ was $44 \%$, and ranged from $38 \%$ (AND32 and LAF34) to $53 \%$ (ARA2). Mean within-population genetic diversity estimates were $P_{\mathrm{p}}=$ $45.3 \pm 3.0, A_{\mathrm{p}}=1.54 \pm 0.04, A P_{\mathrm{p}}=2.17 \pm 0.03$, and $H_{\mathrm{ep}}=$ $0.098 \pm 0.011$. The major differences among populations were detected in levels of expected heterozygosity $\left(H_{\mathrm{ep}}=0.037\right.$ for BUC1, $H_{\mathrm{ep}}=0.195$ for ARA2). No significant association was detected between population densities and $P_{\mathrm{p}}$ (Spearman's rank correlation, $r=-0.066, \mathrm{NS}), A_{\mathrm{p}}(r=-0.071, \mathrm{NS}), A P_{\mathrm{p}}(r=0.191$, NS), and $H_{\text {ep }}(r=-0.175$, NS). The highest levels of genetic diversity occurred on the eastern coast (ARA2, NUE1, NUE6) and part of the mid-western arid region (LAF31 and LAF32). In the northwestern territory (PAR- and LAF-populations), populations with high and low genetic diversity levels occurred in the same geographical units. Two geographically isolated populations, BUC1 in the central coast and AND32 in the frontier with Colombia, had levels of genetic variation comparatively lower than values found for other populations.

\section{Genetic structure}

No significant linkage disequilibrium was detected for any of the 130 possible pairwise locus comparisons performed across all populations. Mean observed heterozygosities $\left(H_{\mathrm{o}}\right)$ were considerably lower than mean expected heterozygosities $\left(H_{\mathrm{ep}}\right)$ for all populations, suggesting a deficiency of heterozygotes within populations throughout the species (Table 2). The highest heterozygote deficiencies were detected in Margarita island (NUE6), the Andean patch (AND32), Araya Peninsula (ARA2), and a population on the northwestern coast (LAF1). Fifty-six out of $112(50 \%)$ fixation indices estimated for each polymorphic locus in each population were positive and significantly different from zero $(P<0.05)$. Seventy-five percent of polymorphic loci and $89 \%$ of populations had $F$-values significantly above zero $(P<0.05)$. Only populations BUC1 and GUA1, both in the central coast, did not have a deficit of heterozygotes. Wright's (1978) mean withinpopulation inbreeding coefficient $\left(F_{\text {IS }}\right)$ was positive and significantly different from zero at the macrogeographic scale (arithmetic mean $F_{\text {IS }}=0.385 \pm 0.077$; weighted mean $\left.F_{\mathrm{IS}}=0.339 \pm 0.013 ; \quad P<0.001\right)$ and within the Mainland (arithmetic mean $F_{\mathrm{IS}}=0.402 \pm$ 0.087 ; weighted mean $F_{\mathrm{IS}}=0.285 \pm 0.021 ; P<0.001$ ) and Peninsula regions (arithmetic mean $F_{\mathrm{IS}}=0.194 \pm$ 0.074 ; weighted mean $F_{\text {IS }}=0.301 \pm 0.031 ; P<0.01$ ) (Table 3). Overall, these results suggest that a moderate level of inbreeding and/or population substructuring occurs within these populations.

Significant allele frequency heterogeneity among populations was detected $(P<0.001)$ for 15 of 17 polymorphic loci $(88.2 \%)$ at the macrogeographical scale, 10 out of 13 loci $(77.0 \%)$ in the Mainland region and 11 out of 15 loci $(73.3 \%)$ in the Peninsula region (Table 3). Twelve rare alleles were restricted to single populations, six alleles were circumscribed within Paraguaná Peninsula populations (PAR-), three alleles were only found in the northwestern area (LAF-), and three were restricted to the eastern coast (ARA2 and NUE-). $F_{\mathrm{ST}}$ estimates were heterogeneous across loci (Table 3). Most loci with relatively low $F_{\mathrm{ST}}$ values were monomorphic for most populations and had a common allele with frequencies above 0.90 . At the macrogeographical level, the arithmetic mean $F_{\mathrm{ST}}$ was $0.193 \pm 0.047$ and the weighted mean $F_{\mathrm{ST}}$ was $0.342 \pm 0.014(P<0.001)$, indicating that around $70 \%$ of the genetic diversity present in $M$. curvispinus is found within populations. Because only one population was randomly chosen from the Mainland and Peninsula regions, the estimate of $F_{\mathrm{ST}}$ represents only one outcome of the various possible combinations of populations that can be chosen from both regions. In order to determine the range of variation of $F_{\mathrm{ST}}$ 


\begin{tabular}{|c|c|c|c|c|c|c|c|}
\hline Level & $N$ & $\% P$ & $A P$ & $A$ & $\% A l$ & $H_{\mathrm{o}}$ & $H_{\mathrm{e}}$ \\
\hline Species & 864 & 89.5 & 3.82 & 3.53 & $66^{*}$ & - & 0.145 \\
\hline \multicolumn{8}{|l|}{ Region } \\
\hline Pooled & 240 & 68.4 & 2.85 & 2.26 & 65.2 & - & 0.157 \\
\hline Population mean & & 46.3 & 2.25 & 1.58 & - & 0.080 & 0.111 \\
\hline SE & & 5.4 & 0.04 & 0.07 & - & 0.018 & 0.019 \\
\hline \multicolumn{8}{|l|}{ Peninsula } \\
\hline Pooled & 240 & 79.0 & 2.47 & 2.16 & 62.1 & - & 0.093 \\
\hline Population mean & & 46.3 & 2.16 & 1.54 & - & 0.057 & 0.080 \\
\hline $\mathrm{SE}$ & & 4.5 & 0.05 & 0.06 & - & 0.009 & 0.008 \\
\hline \multicolumn{8}{|l|}{ Population } \\
\hline AND32 & 48 & 26.3 & 2.20 & 1.32 & 37.9 & 0.028 & 0.052 \\
\hline ARA2 & 48 & 57.9 & 2.45 & 1.84 & 53.0 & 0.121 & 0.195 \\
\hline BUC1 & 48 & 21.1 & 2.00 & 1.21 & 34.8 & 0.029 & 0.037 \\
\hline GUA1 & 48 & 42.1 & 2.13 & 1.47 & 42.4 & 0.095 & 0.109 \\
\hline LAF1 & 48 & 42.1 & 2.13 & 1.47 & 42.4 & 0.020 & 0.070 \\
\hline LAF21 & 48 & 36.8 & 2.00 & 1.37 & 39.4 & 0.034 & 0.054 \\
\hline LAF31 & 48 & 57.9 & 2.18 & 1.68 & 48.5 & 0.118 & 0.150 \\
\hline LAF32 & 48 & 52.6 & 2.40 & 1.74 & 50.0 & 0.110 & 0.164 \\
\hline LAF33 & 48 & 47.4 & 2.22 & 1.58 & 45.5 & 0.063 & 0.091 \\
\hline LAF34 & 48 & 26.3 & 2.20 & 1.32 & 37.9 & 0.058 & 0.081 \\
\hline LAF35 & 48 & 47.4 & 2.22 & 1.58 & 45.5 & 0.053 & 0.070 \\
\hline NUE1 & 48 & 63.2 & 2.00 & 1.63 & 45.5 & 0.122 & 0.144 \\
\hline NUE6 & 48 & 63.2 & 2.17 & 1.74 & 50.0 & 0.064 & 0.156 \\
\hline PAR1 & 48 & 47.4 & 2.22 & 1.58 & 45.5 & 0.042 & 0.068 \\
\hline PAR6 & 48 & 63.2 & 2.17 & 1.74 & 50.0 & 0.085 & 0.109 \\
\hline PAR7 & 48 & 42.1 & 2.00 & 1.42 & 40.9 & 0.048 & 0.079 \\
\hline PAR8 & 48 & 36.8 & 2.29 & 1.47 & 42.4 & 0.052 & 0.059 \\
\hline PAR9 & 48 & 42.1 & 2.13 & 1.47 & 42.4 & 0.058 & 0.082 \\
\hline Mean** & & 45.3 & 2.17 & 1.54 & 44.1 & 0.067 & 0.098 \\
\hline SE & & 3.0 & 0.03 & 0.04 & 1.17 & 0.008 & 0.011 \\
\hline
\end{tabular}

$N$, number of individuals in the population sample; $P$, proportion of polymorphic loci;

$A$, mean number of alleles per locus; $A P$, mean number of alleles per polymorphic locus;

$\% \mathrm{Al}$, percentage of total number of alleles identified; $H_{\mathrm{o}}$, mean observed heterozygosity;

$H_{\mathrm{e}}$, mean Hardy-Weinberg expected heterozygosity.

*Total number of alleles in the species.

** Means include 19 loci, 17 of which are polymorphic.

estimates, mean values across loci were calculated for all possible combinations of populations at the macrogeographical level. Average $F_{\mathrm{ST}}$ estimates obtained across all combinations of populations were $0.195 \pm 0.004$ (arithmetic mean) and $0.349 \pm 0.004$ (weighted mean), very similar to the values obtained for a single combination of populations. At the regional level, the $F_{\mathrm{ST}}$ for the Mainland region (arithmetic mean $F_{\mathrm{ST}}=0.187 \pm 0.059$; weighted mean $\left.F_{\mathrm{ST}}=0.324 \pm 0.022 ; P<0.001\right)$ was higher than the value for the Peninsula region (arithmetic mean $F_{\mathrm{ST}}=0.084 \pm 0.036$; weighted mean $F_{\mathrm{ST}}=0.150 \pm$ $0.021 ; P<0.01$ ), suggesting more population differentiation in the former region; however, differences between regional estimates were not statistically significant ( $95 \%$ C.I. based on bootstrapping over loci).
Table 2 Genetic diversity estimates at the species, region, and population level for Melocactus curvispinus in Venezuela 
Table 3 Nei (1977) estimates of genetic diversity and Weir \& Cockerham (1984) estimates of $F$-statistics for 17 polymorphic loci in Melocactus curvispinus at macrogeographic and regional (Mainland and Peninsula) scales. Arithmetic means and SE across loci are included

\begin{tabular}{|c|c|c|c|c|c|c|c|c|c|c|c|c|}
\hline \multirow[b]{2}{*}{ Locus } & \multicolumn{4}{|c|}{ Macrogeographic range $(N=9)$} & \multicolumn{4}{|c|}{ Mainland region $(N=5)$} & \multicolumn{4}{|c|}{ Peninsula region $(N=5)$} \\
\hline & $H_{\mathrm{T}}$ & $H_{\mathrm{S}}$ & $F_{\text {IS }}$ & $F_{\mathrm{ST}}$ & $H_{\mathrm{T}}$ & $H_{\mathrm{S}}$ & $F_{\text {IS }}$ & $F_{\mathrm{ST}}$ & $H_{\mathrm{T}}$ & $H_{\mathrm{S}}$ & $F_{\mathrm{IS}}$ & $F_{\mathrm{ST}}$ \\
\hline Aat-1 & 021 & 0.020 & $0.345^{* *}$ & $0.020^{*}$ & 072 & 0.070 & $0.295^{*}$ & $0.025^{*}$ & 0.012 & 0.012 & -0.022 & $0.021 *$ \\
\hline Aat-2 & 224 & 0.147 & $455^{* *}$ & $365^{* *}$ & 429 & 0.153 & $0.222 *$ & $0.688^{* *}$ & 0.255 & 0.131 & $0.750 * *$ & $0.533 * *$ \\
\hline Dia-1 & 142 & 0.113 & $0.566^{* *}$ & $0.208^{* *}$ & 0.392 & 0.274 & $0.611^{* *}$ & $0.340 * *$ & 0.103 & 0.085 & 0.030 & $0.196^{*}$ \\
\hline Dia-3 & 338 & 0.276 & 0.571 & $0.190^{* *}$ & 0.431 & 0.257 & 0.50 & $0.449 *$ & 0.279 & 0.229 & $0.722 * *$ & $0.199 *$ \\
\hline $\mathrm{Fe}-2$ & 202 & 0.146 & 0.11 & 0 & 0.338 & 0.293 & 0.14 & 0.15 & 0.104 & 0.098 & -0.015 & $0.065^{*}$ \\
\hline Gdh-1 & 0.016 & 0.016 & $0.271 *$ & $0.026^{*}$ & 0.017 & 0.016 & $0.497 * *$ & 0.003 & - & - & - & - \\
\hline$I d h-1$ & 048 & 0.045 & $0.310^{* *}$ & 1** & 0.123 & 0.118 & $0.196^{*}$ & $0.036^{* *}$ & 0.064 & 0.059 & $0.443 *$ & $0.091 *$ \\
\hline Lap-1 & 366 & 0.280 & 0.45 & $0.246^{* *}$ & 0.249 & 0.206 & $0.402 * *$ & $0.194 * *$ & 0.008 & 0.008 & -0.005 & 0.005 \\
\hline$M d h-2$ & 366 & 0.135 & & 0.65 & - & - & - & - & 0.250 & 0.241 & 98* & $0.030^{*}$ \\
\hline$M d h-3$ & 0.005 & 0.004 & 0.800 & 0.000 & 0.008 & 0.008 & 1.000 & 0.000 & 0.004 & 0.004 & 0.000 & 0.000 \\
\hline$M n r-1$ & 0.007 & 0.007 & $0.667^{* *}$ & 0.000 & 0.008 & 0.008 & 1.000 ** & 0.000 & - & - & - & - \\
\hline Pgi-1 & 0.154 & 0.122 & -0.030 & $220^{* *}$ & - & - & - & - & 0.008 & 0.008 & -0.011 & 0.011 \\
\hline Pgm-2 & 0.102 & 0.086 & $0.544 * *$ & $0.162^{* *}$ & - & - & - & - & 0.115 & 0.111 & $0.593 *$ & $0.030^{*}$ \\
\hline Tpi-1 & 0.005 & 0.004 & & 0.000 & 0.095 & 0.084 & 0.121 & $0.126^{* *}$ & 0.012 & 0.012 & -0.022 & $0.021 *$ \\
\hline Tpi-2 & 0.009 & 0.009 & -0.011 & & - & - & - & - & 0.025 & 0.024 & -0.014 & 0.005 \\
\hline Ugpp-1 & 0.486 & 308 & $73^{* *}$ & $386^{* *}$ & 0.514 & 0.360 & 0.109 & 0.341 & 0.445 & 0.428 & 0.101 & $0.036^{*}$ \\
\hline Ugpp-2 & 0.330 & 0.189 & $0.229 * *$ & $0.450^{* *}$ & 0.300 & 0.280 & 0.118 & $0.071^{* *}$ & 0.081 & 0.079 & $0.162 *$ & $0.023^{*}$ \\
\hline & & & & & 0.229 & 0.164 & 0.40 & & 011 & 0.102 & & 0.084 \\
\hline SE & 0.039 & 0.025 & 0.077 & 0.047 & 0.051 & 0.034 & 0.087 & 0.059 & 0.034 & 0.030 & 0.074 & 0.036 \\
\hline
\end{tabular}

$\mathrm{N}$, number of populations; $H_{\mathrm{T}}$, total genetic diversity; $H_{\mathrm{S}}$, within population genetic diversity; $F_{\mathrm{IS}}$, within population inbreeding coefficient; $F_{\mathrm{ST}}$, proportion of total gene diversity found among populations.

Significant at $* P<0.05$ and $* * P<0.001$, respectively.

including entities that belonged to the Mainland region (LAF3-) and population GUA1 on the central coast. The UPGMA phenogram partially matched geographical relationships among populations (Fig. 3). The most meaningful cluster in geographical terms separated all populations in the east coast (BUC1, ARA2 and NUE-) from the remaining entities. A second cluster grouped most elements of western Venezuela, from Paraguaná Peninsula (PAR-) to Ureña (AND32). Grouping inside of this cluster, however, was not concordant with geographical distances that separate most populations.

\section{Discussion}

\section{Genetic diversity}

Compared to other flowering plant species, M. curvispi$n u s$ is relatively rich in polymorphic loci $(P)$ and number of alleles per polymorphic locus $(A P)$, but with only average levels of heterozygosity $\left(H_{\mathrm{e}}\right)$ (Table 4 ) (Hamrick \& Godt, 1989; Hamrick et al., 1992). Many of the polymorphic loci surveyed had one allele in high frequency, a pattern that has been detected in other cactus species (Nassar, 1999; Hamrick et al., 2001). Compared to long-lived woody species with mixed- animal breeding systems, $M$. curvispinus has at least twice the genetic diversity at both the species and population levels (Hamrick et al., 1992). Besides M. curvispinus, eight other cactus species have been surveyed for allozyme diversity under similar protocols and across several populations (Nassar, 1999; Hamrick et al., in press) (Table 4). Compared to them, M. curvispinus exhibited similar values of $P_{\mathrm{s}}, A_{\mathrm{s}}$ and $A P_{\mathrm{s}}$, but showed relatively lower heterozygosity at the species and population levels. The results found for M. curvispinus are consistent with the general observation that mixedmating taxa tend to have less genetic diversity than predominantly outcrossing plants (Hamrick \& Godt, 1989; Hamrick et al., 1992). All the other cacti studied, with the exception of hermaphroditic individuals of the Mexican-American $P$. pringlei (Murawski et al., 1994) and Weberbauerocereus weberbaueri in Peru (Sahley, 1996), are obligate outcrossers (Leuenberger, 1986; Fleming et al., 1996; Nassar et al., 1997; Nassar, 1999).

Populations with the highest levels of genetic variation were distributed in two zones in Venezuela, the mid-western arid region and the coastal zone in the east. Interestingly, some populations within the former area (LAF34 and LAF35) had substantially less genetic

(C) The Genetics Society of Great Britain, Heredity, 87, 69-79. 


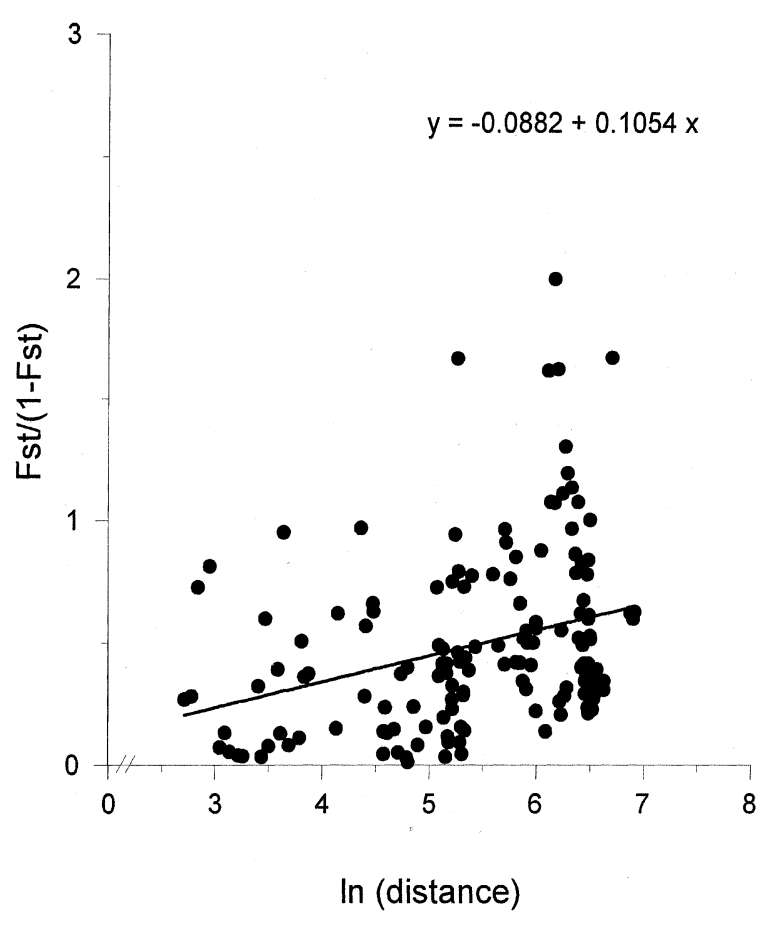

Fig. 2 Differentiation among Melocactus curvispinus populations. Multilocus estimates of pairwise differentiation $\left(F_{\mathrm{ST}} /\left(1-F_{\mathrm{ST}}\right)\right)$ are plotted against natural logarithm of geographical distances (in km) according to Rousset (1997). $R^{2}=0.100$.

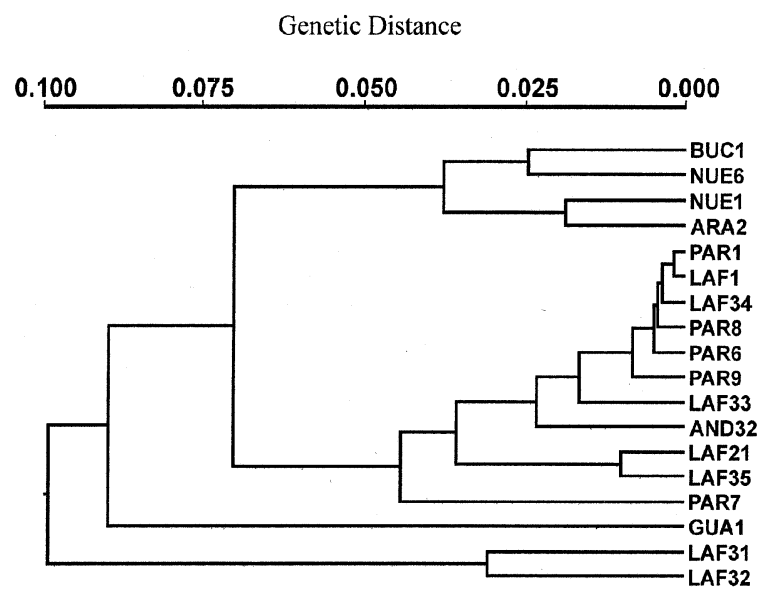

Fig. 3 UPGMA clustering based on Nei's genetic distances $(D)$ estimated for 18 populations of Melocactus curvispinus.

Populations were sampled across the geographical distribution in Venezuela.

diversity than other nearby populations. Compared to others in the region, these two populations are located within highly disturbed agricultural areas. Populations in such disturbed environments may have passed through genetic bottlenecks, and the disturbances may have produced physical barriers that reduced gene exchange among populations. Populations BUC1 in the central coast and AND32 in the Andes had the lowest levels of genetic diversity. Both localities represent geographically isolated populations of $M$. curvispinus, in which genetic drift might have reduced genetic variability. In contrast, a relatively restricted arid zone on the eastern coast of Venezuela (NUE-and ARA2) contained high levels of genetic variation. The expectations for this zone were contrary to the pattern observed, since the species' range in that part of the country is relatively narrow. However, during the last Glacial Maximum (18 $000 \mathrm{yr}$ BP), when the general climate in Venezuela was drier than at present (Schubert, 1988) the area covered by arid vegetation in the eastern part of the country was probably broader, maintaining larger and, apparently, genetically diverse populations.

Levels of genetic diversity were only slightly higher for the Mainland compared to the Peninsula region. In a similar study comparing Pereskia guamacho populations between these two areas (Nassar, 1999), populations in the Mainland region had significantly more genetic diversity than in the Peninsula. It is tempting to attribute the observed patterns to the greater spatial isolation of cactus populations on the peninsula with respect to the mainland, but the two populations of Melocactus surveyed in Margarita island had higher or equivalent levels of genetic diversity to all populations examined in the Peninsula region. However, the Margarita island populations are relatively dense (198-483 ind/ha) and continuously distributed along the coast and lowlands.

\section{Genetic structure}

A deficiency of heterozygotes was observed in most populations, reflecting the mixed-mating system $\left(t_{\mathrm{m}}=0.764\right.$ for population LAF32) of $M$. curvispinus (Nassar, 1999). Inbreeding through selfing may play a significant role in the genetic make-up of this species. In addition, part of the heterozygote deficiency observed within populations could also be the product of population substructuring (Heywood, 1991). Hummingbirds are important pollinators of Melocactus flowers (Taylor, 1991). Many hummingbird species defend well-defined patches of flowers (territories) from other heterospecific and conspecific floral visitors (Calder, 1990). It is possible that during peak flowering $M$. curvispinus becomes suitable for territorial defense by hummingbirds. This is the case for Melocactus salvadorensis, a species pollinated by the Ruby-Topaz hummingbird (Chrysolampis mosquitus) in the dry caatinga of northeastern Brazil (Raw, 1996). That foraging strategy, coupled with local seed dispersal, could generate genetic 
Table 4 Allozyme diversity estimates for Melocactus curvispinus, other species of cactus, long-lived woody taxa, and all plant species. Estimates are at the species level

\begin{tabular}{lccccccc}
\hline Taxa & $\begin{array}{c}\text { No. of } \\
\text { species }\end{array}$ & $\begin{array}{c}\text { Mean } \\
\text { no. loci }\end{array}$ & $P_{\mathrm{s}}$ & $A P_{\mathrm{s}}$ & $H_{\mathrm{es}}$ & $G_{\mathrm{ST}}$ & Source \\
\hline$M$. curvispinus & 1 & 19.0 & 89.47 & 3.82 & 0.145 & $0.193^{*}$ & This study \\
Cacti & 8 & 22.8 & 91.8 & 3.32 & 0.208 & 0.112 & a, c \\
Woody & 191 & 18.1 & 65.0 & 2.22 & 0.177 & 0.084 & $\mathrm{~b}$ \\
All plant species & 655 & 17.3 & 51.3 & 1.97 & 0.150 & 0.228 & $\mathrm{~b}$ \\
\hline
\end{tabular}

$P$, proportion of polymorphic loci; $A P$, mean number of alleles per polymorphic locus; $H_{\mathrm{e}}$, mean Hardy-Weinberg expected heterozygosity; $G_{\mathrm{ST}}$, proportion of total genetic diversity due to differences among populations.

${ }^{\mathrm{a}}$ Nassar, 1999, ${ }^{\mathrm{b}}$ Hamrick et al., 1992, ${ }^{\mathrm{c}} \mathrm{Hamrick}$ et al., 2001.

*Mean $F_{\mathrm{ST}}$ estimate following Weir \& Cockerham (1984).

subdivision and small neighbourhood sizes and areas within Melocactus populations (Turner et al., 1982). Lizards, which are important seed dispersers of this genus (Taylor, 1991; Côrtes-Figueira et al., 1994), generally have limited dispersal abilities (Rose, 1982), therefore contributing to both increased inbreeding and genetic subdivision within the Melocactus populations.

Significant genetic differentiation among populations of $M$. curvispinus was detected both at the macrogeographical and at the regional levels. Mean $F_{\mathrm{ST}}$ values were similar between the macrogeographic range $(0.193 \pm 0.047)$ and the Mainland subset $(0.187 \pm$ $0.059)$. The Peninsula region had less genetic differentiation among populations $(0.084 \pm 0.036)$. This regional difference can be explained in part by a more uniform and flattened landscape in the Paraguaná Peninsula compared to the Mainland region, that could facilitate genetic exchange among populations. Overall, these results suggest that historically, $M$. curvispinus has had moderate to low levels of gene flow across its geographical distribution in Venezuela.

Melocactus curvispinus had significantly more interpopulation differentiation than average values reported for 191 long-lived woody species $\left(G_{\mathrm{ST}}=0.084\right)$ (Table 4), 37 animal-pollinated woody plants $\left(G_{\mathrm{ST}}=\right.$ 0.099), 12 animal-pollinated mixed-mating species $\left(G_{\mathrm{ST}}=0.122\right)$, and 14 taxa with animal-ingested seed dispersal $\left(G_{\mathrm{ST}}=0.051\right)$ (Hamrick et al., 1992). This species also had comparatively higher $F_{\mathrm{ST}}$ values than most cacti studied $(N=8)$ over similar geographical areas (mean $G_{\mathrm{ST}}=0.112$, mean; Table 4) (Nassar, 1999; Hamrick et al., 2001). As indicated previously, most of those cacti are predominantly outcrossing. In general, selfing and mixed-mating plants have more genetic differentiation among populations than outcrossing plant taxa (Hamrick \& Godt, 1989, 1996). As stated before, restricted pollination and seed dispersal can also significantly increase population structure (Turner et al.,
1982). Lophocereus schottii, a self-incompatible, mothpollinated columnar cactus (Fleming \& Holland, 1998), had more population differentiation than other outcrossing columnar cacti examined in Mexico, southwestern USA and Venezuela $\left(G_{\mathrm{ST}}=0.242\right)$ (Hamrick et al., in press). This species and M. curvispinus have in common pollen vectors with apparently restricted dispersal abilities. Although small moths can perform long-distance flights, most pollination events by these insects seem to occur over relatively short distances (Pellmyr et al., 1997). In the case of M. curvispinus, its hummingbird pollinators might have a relatively small foraging area if they defend a floral resource during the peak flowering period. Taylor (1991) has suggested previously that restricted hummingbird foraging could lead to genetic isolation among melocacti populations; our data appear to support his hypothesis.

Our test for isolation-by-distance (Rousset, 1997) indicated a weak but significant relationship between levels of genetic exchange and geographical distances separating Melocactus populations. Theoretically, the absence of isolation-by-distance could be indicative of randomized gene dispersal (island model). In the case of $M$. curvispinus, however, it is more plausible to interpret the pattern observed as evidence of effective population isolation (Slatkin, 1993). The moderate $F_{\mathrm{ST}}$ value observed for $M$. curvispinus suggests that gene movement among populations may be relatively limited and that genetic drift may play a significant role in the spatial genetic structuring of this species.

Nei's (1972) genetic identity values were relatively high for most population pairs (mean $I=0.942$ ) and within the range attributed to conspecific populations (Crawford, 1989). This result is in agreement with Taylor's (1991) proposition of a single species of $M$. curvispinus including all populations of this cactus in Venezuela. At the level of resolution that allozyme variation allows, four genetically related groups of populations can be separated: (i) a well-delimited cluster 
in the east coast (BUC1, NUE-, ARA2); (ii) an isolated element in the central coast (GUA); (iii) a large cluster embracing populations from the Paraguaná Peninsula to the frontier with Colombia (PAR-, LAF3-, LAF21, LAF1 and AND32); and (iv) a subgroup conformed by two populations (LAF31 and LAF32) belonging to the mid-western region. This pattern, however, does not reflect Taylor's (1991) taxonomic subdivision of M. curvispinus in Venezuela. According to Taylor, M. curvispinus curvispinus ranges from Ureña, on the Colombian border, to mid-western Venezuela. The other subspecies, M. curvispinus caesius, is found mostly along the coast. Even though Crawford (1989) has stated that infraspecific subdivisions of taxa are not necessarily reflected by patterns of allozyme variation, the results of this study call for a reconsideration of the taxonomic subdivision of this species in Venezuela.

Overall, the present results suggest that in M. curvispinus, the combination of mixed-mating and restricted animal-mediated gene dispersal, have led to higher genetic heterogeneity among populations and somewhat lower within-population genetic variation than levels observed in other cactus species with more extensive gene dispersal. Melocactus curvispinus therefore represents a moderately genetically structured species that may potentially be more exposed to speciation processes than Venezuelan cacti with obligate xenogamy and extensive gene dispersal. In Central and South America, the genus Melocactus includes 24 species and 10 heterotypic subspecies (Taylor, 1991). While other genera, such as Stenocereus, Pilosocereus and Pereskia, are represented in Venezuela by only one or two species (Hunt, 1999), five species of Melocactus have been identified. Furthermore, within M. curvispinus, three subspecies and two varieties of one subspecies have been recognized. Although the results of this study do not negate the infraspecific subdivision proposed for Venezuela, they should stimulate a revision of the geographical ranges associated with each subspecies.

\section{Acknowledgements}

We thank Janet Castro, Mindy Burke, Rebecca Pappert and Beate Rüeter for field and laboratory assistance. Andy Tull and Melany Smith provided greenhouse assistance. Stewart Schultz, Ken Spitze and Keith Waddington provided helpful comments on a former version of this manuscript. We also wish to thank the valuable input of two anonymous reviewers. This research was partially funded by NSF Supplementary Grant DEB-9421673 (to THF), NSF Grant DEB-9420254 (to JLH), Tropical Biology Fellowship and Curtis Scholarship of University of Miami (to JMN), Cactus and Succulent Society of America
Research Grant (to JMN) and Horticulture Society of South Florida Research Grant (to JMN). Fundación Instituto Botánico de Venezuela and the Ministry of Agriculture provided seed collection and exportation permits.

\section{References}

BERG, E. E. AND HAMRICK, J. L. 1997. Quantification of genetic diversity at allozyme loci. Can. J. Forest. Res., 27, 415-424.

CALDER, w. A. 1990. Territorial hummingbirds. Nat. Geog. Res., 7, 56-69.

CHELIAK, W. M. AND PITEL, J. A. 1984. Techniques for Starch Gel Electrophoresis of Enzymes from Forest Tree Species. Petawawa National Forestry Institute, Information Report P1-X-42. Canadian Forestry Service Chalk River, Ontario, Canada.

CÔRTES-FigueirA, J. E., VASCONCELlos-Neto, J., GARCiA, M. A. AND TEXeIRA DE SOUZA, A. L. 1994. Saurocory in Melocactus violaceus (Cactaceae). Biotropica, 26, 295-301.

CRAWFORD, D. J. 1989. Enzyme electrophoresis and plant systematics. In: Soltis, D. E. and Soltis, P. S. (eds) Isozymes in Plant Biology, pp. 146-164. Dioscorides Press, Portland, OR.

DAS, A. B., MOHANTY, S. AND DAS, P. 1998. Variation in karyotype and 4C DNA content in six species of Melocactus of the family Cactaceae. Cytologia, 63, 9-16.

FLEMING, T. H. AND HOLLAND, J. N. 1998. The evolution of obligate mutualisms: the senita and senita moth. Oecologia, 114, 368-378.

FLEMING, T. H., TUTTLE, M. D. AND HORNER, M. A. 1996. Pollination biology and the relative importance of nocturnal and diurnal pollinators in three species of Sonoran Desert columnar cacti. Southwest. Nat., 41, 257-269.

GARNIER-GERE, P. AND DILLMAN, C. 1992. A computer program for testing pairwise linkage disequilibria in subdivided populations. J. Hered., 83, 239.

Gibson, A. C. AND Nobel, P. S. 1990. The Cactus Primer. Harvard University Press, Cambridge, MA.

HAMRICK, J. L. AND GODT, M. J. 1989. Allozyme diversity in plant species. In: Brown, A. H. D., Clegg, M. T., Kahler, A. L. and Weir, B. S. (eds) Plant Population Genetics, Breeding and Genetic Resources, pp. 43-63. Sinauer Associates, Sunderland, MA.

HAMRICK, J. L. AND GODT, M. J. 1996. Effects of life history traits on genetic diversity in plant species. Phil. Trans. R. Soc. B, 351, 1291-1298.

HAMRICK, J. L., GODT, M. J. AND SHERMAN-BROYLES, S. L. 1992. Factors influencing levels of genetic diversity in woody plant species. New Forests, 6, 95-124.

HAMRICK, J. L., NASON, J. D., FLEMING, T. H. AND NASSAR, J. M. 2001. Genetic Diversity in Columnar Cacti. In: Fleming, T. H. and Valiente-Banuet, A. (eds) Evolution, Ecology and Conservation of Columnar Cacti and Their Mutualists. University of Arizona Press, AZ, in press.

HEYwOOD, J. S. 1991. Spatial analysis of genetic variation in plant populations. Ann. Rev. Ecol. Syst., 22, 335-355.

(c) The Genetics Society of Great Britain, Heredity, 87, 69-79. 
HuNT, D. 1999. CITES Cactaceae Checklist, 2nd edn. Royal Botanic Gardens Kew, Milborne Port.

Leuenberger, B. E. 1986. Pereskia (Cactaceae). Mem. N.Y. Bot. Gard., 41, 2-139.

LOVELESS, M. D. AND HAMriCK, J. L. 1984. Ecological determinants of genetic structure in plant populations. Ann. Rev. Ecol. Syst., 15, 65-95.

MARTINEZ-PALACIOS, A., EGUIARTE, L. E. AND FURNIER, G. R. 1999. Genetic diversity of the endangered endemic Agave victoriae-reginae (Agavaceae) in the Chihuahuan Desert. Am. J. Bot., 861, 1093-10984.

MITTON, J. B., LINHART, Y. B., STURGEON, K. B. AND HAMRICK, J. L. 1979. Allozyme polymorphism detected in mature needle tissue of ponderosa pine. J. Hered., 70, 86-89.

MURAWSKI, D. A., FLEMING, T. H., RITLAND, K. AND HAMRICK, J. L. 1994. Mating system of Pachycereus pringlei: an autotetraploid cactus. Heredity, 72, 86-94.

NASSAR, J. M. 1999. Comparative population genetic structure of Venezuelan cacti and estimates of their mating systems. Ph.D. dissertation, University of Miami, Coral Gables, FL.

NASSAR, J. M., RAMIREZ, N. AND LINARES, O. 1997. Comparative pollination biology of Venezuelan columnar cacti and the role of nectar-feeding bats in their sexual reproduction. Am. J. Bot., 84, 918-927.

NEI, M. 1972. Genetic distance between populations. Am. Nat., 106, 283-292.

NEI, M. 1977. F-statistics and analysis of gene diversity in subdivided populations. Ann. Hum. Genet., 41, 225-233.

PELlmyR, O., MASSEY, L. K., HAMRICK, J. L. AND FEIST, M. A. 1997. Genetic consequences of specialization: yucca moth behavior and self-pollination in yuccas. Oecologia, 109, 273-278.

RAw, A. 1996. Territories of the Ruby-Topaz hummingbird, Chrysolampis mosquitus at flowers of the 'Turk's-Cap' cactus, Melocactus salvadorensis in the dry caatinga of north-eastern Brazil. Rev. Bras. Biol., 56, 581-584.

RAYMOND, M. AND ROUSSET, F. 1995a. GENEPOP (Version 1.2): population genetics software for exact tests and ecumenicism. J. Hered., 86, 248-249.

RAYMOND, M. AND ROUSSET, F. 1995b. An exact test for population differentiation. Evolution, 49, 1280-1283.
ROHLF, F. J. 1993. NTSYS-PC: Numerical taxonomy and multivariate analysis system, v.1.80. Exeter Software, Setauket, NY.

RoMesburg, H. C. 1984. Cluster Analysis for Researchers. Lifetime Learning Publications, Belmont, CA.

ROSE, B. 1982. Lizard home ranges: methodology and functions. J. Herpet., 16, 253-269.

ROUSSET, F. 1997. Genetic differentiation and estimation of gene flow from F-statistics under isolation by distance. Genetics, 145, 1219-1228.

ROUSSET, F. AND RAYMOND, M. 1995. Testing heterozygote excess and deficiency. Genetics, 140, 1413-1419.

SAHLEY, C. T. 1996. Bat and hummingbird pollination of an autotetraploid columnar cactus, Weberbauerocereus weberbaueri (Cactaceae). Am. J. Bot., 83, 1329-1336.

SARMIENTO, G. 1976. Evolution of arid vegetation in tropical America. In: Goodall, D. W. (ed.) Evolution of Desert Biota, pp. 65-100. University of Texas Press, Austin, TX.

SCHUBERT, C. 1988. Climatic changes during the last glacial maximum in northern South America and the Caribbean: a review. Interciencia, 13, 128-137.

SLATKIN, M. 1993. Isolation by distance in equilibrium and non-equilibrium populations. Evolution, 47, 264-279.

SOLTIS, D. E., HAUfLER, C. H., DARROW, D. C. AND GASTONY, G. J. 1983. Starch gel electrophoresis of ferns: a compilation of grinding buffers, gel and electrode buffers, and staining schedules. Am. Fern. J., 73, 9-27.

TAYLOR, N. P. 1991. The genus Melocactus (Cactaceae) in Central and South America. Bradleya, 9, 1-80.

TURNER, M. E., STEPHENS, J. C. AND ANDERSON, W. W. 1982. Homozygosity and patch structure in plant populations as a result of nearest-neighbor pollination Proceedings Natl. Acad. Sci. USA, 79, 203-207.

WEIR, B. S. AND COCKERHAM, C. C. 1984. Estimating F-statistics for the analysis of population structure. Evolution, 38, 13581370 .

WENDEL, J. F. AND PARKS, C. R. 1982. Genetic control of isozyme variation in Camelia japonica L. J. Hered., 73, 197-204.

WRIGHT, s. 1978. Evolution and Genetics of Populations, Vol. 4: Variability Among Natural Populations. The University of Chicago Press, Chicago, IL. 